\title{
STRENGTH PROPERTIES AND DURABILITY ASPECTS OF SINTERED-FLY-ASH LIGHTWEIGHT AGGREGATE CONCRETE
}

\section{TRDNOST IN TRAJNOST BETONA Z IZBRANO VSEBNOSTJO LAHKIH SINTRANIH AGREGATOV IZ DIMNIŠKEGA PEPELA}

\author{
Nagarajan Divyah $^{1 *}$, Rajagopal Thenmozhi ${ }^{1}$, Meyappan Neelamegam ${ }^{2}$ \\ ${ }^{1}$ Department of Civil Engineering, Government College of Technology, Coimbatore-641013, Tamil Nadu, India \\ ${ }^{2}$ Department of Civil Engineering, Easwari Engineering College, Easwari Egnineering College, Chennai-600089, India
}

Prejem rokopisa - received: 2019-07-10; sprejem za objavo - accepted for publication: 2019-12-23

doi:10.17222/mit.2019.101

\begin{abstract}
The effect of basalt fibre on concrete made with sintered-fly-ash aggregates as coarse aggregates, a by-product of the processing of fly ash is studied in detail with respect to its strength, durability and cost effectiveness and compared with normal aggregate concrete. Four different mixes were developed for the M25, M30 and M40 grades of concrete with $0.25 \%$ of basalt fibre in each mix. The rebound hammer test, ultrasonic pulse velocity, compressive strength, split tensile strength, flexural strength, Young's modulus, sorptivity and ponding test were investigated and a stress-strain curve was plotted. A linear-regression analysis was carried out to find the relationship between the mechanical properties of the concrete. A cost analysis worked to find the cost effectives of using the sintered-fly-ash aggregate. The findings indicated that the addition of basalt fibre showed a marginal increase in the compressive strength and a substantial increase in the split tensile strength and flexural strength was observed. The Young's modulus of the sintered-fly-ash aggregate concrete was low when compared with the conventional mix. The sorptivity test and the ponding test revealed that the sintered-fly-ash aggregate concrete showed a considerable decrease in durability. The outcome of the cost analysis showed that the use of sintered-fly-ash aggregate concrete reduced the cost by $12 \%$ when compared with conventional route. The experimental test results throw light on the use of sintered-fly-ash aggreagte in concrete and basalt fibre proves the effectiveness of the lightweight concrete developed.
\end{abstract}

Keywords: non-destructive testing, stress-strain, empirical equations, durability

Avtorji v pričujočem članku opisujejo raziskavo vpliva dodatka bazaltnih vlaken in grobih sintranih agregatov iz dimniškega pepela $\mathrm{k}$ betonu. Ugotavljali so trdnost, trajnost in stroške izdelave tega betona v primerjavi z betonom, ki vsebuje agregate normalne velikosti. Izdelali so štiri različne mešanice za betone vrst: M25, M30 in M40 z 0,25\% bazaltnih vlaken v vsaki mešanici. Na izdelanih vzorcih betona so izvedli udarno-odbojni preizkus, merili ultrazvočno pulzno hitrost, izvedli tlačni in upogibni preizkus, določili odvisnost med napetostjo in deformacijo ter Youngov modul, določili sorpcijo (kapilarno absorbcijo) in izvedli test absorpcije z namakanjem v vodi. Nato so izvedli še linearno regresijo, da bi ugotovili povezave med mehanskimi lastnostmi betonov. Stroškovna analiza je bila namenjena ugotavljanju vpliva dodatka sintranih agregatov iz dimniškega pepela na ceno betona. Betoni s sintranimi agregati so $12 \%$ cenejši. Avtorji ugotavljajo, da ima dodatek bazaltnih vlaken zanemarljiv vpliv na tlačno trdnost betonov, občutno pa sta se povečali njihova natezna in upogibna trdnost. V primerjavi s konvencionalno mešanico, so imele mešanice $\mathrm{z}$ dodatkom sintranih agregatov iz dimniškega pepela manjši Youngov modul. Preizkusa sorpcije in potapljanja sta pokazala, da imajo vzorci, ki vsebujejo sintrane agregate iz dimniškega pepela, precej krajšo dobo trajanja. Eksperimentalni rezultati so pokazali prednost uporabe sintranih agregatov iz dimniškega pepela in bazaltnih vlaken predvsem za učinkovito zmanjšanje mase betonov oziroma je njihova uporaba aktualna pri razvoju lahkih betonov.

Ključne besede: neporušitvene preiskave, krivulje odvisnosti med napetostjo in deformacijo, empirične enačbe, trajnost

\section{INTRODUCTION}

Concrete is selected for its mechanical behaviour, like compression, split tension and flexure. But it was effective while the resources used for forming concrete were abundantly available. The natural resources that form the major ingredient for concrete are in greater demand now and are less available. Therefore, research is now concentrating on optimized performance characteristics for the given set of materials, usage, and exposure conditions, consistent with the requirements of cost, service life and durability.

These materials should cater to the needs for making concrete with higher strength, better workability, better volume stability, and higher durability. ${ }^{1}$ The use of con-

*Corresponding author's e-mail:

divyah991@gmail.com (Divyah Nagarajan) struction materials that caters for the problems faced by the depletion of natural resources and the associated problems related to the disposal of industrial waste products have been increased in recent times. This can be solved by using industrial by-products as the constituents of concrete.

Lightweight concrete (LWC) is a very versatile material for construction. It has a range of technical, economic and environment-enhancing and preserving advantages and is destined to become the dominant material for construction in the new millennium. ${ }^{2}$ The only perceived limitation of LWC is that it requires manufactured lightweight aggregates (LWAs). Therefore, the use of artificial aggregates has shown reasonable costs and produces better quality compared to conventional aggregates. ${ }^{3}$ Structural concrete is now available with a density range $1800-3000 \mathrm{~kg} / \mathrm{m}^{3}$ as lightweight, normal weight and 
heavyweight concrete. ${ }^{4}$ The sintered-fly-ash lightweight aggregate proves to be a consistent and better construction material..$^{5}$ The sintered-fly-ash aggregate is produced from a sintering process of fly ash. They prove to be consistent, superior, lightweight and better materials for construction purposes. Nowadays, these lightweight sintered-fly-ash aggregates are used for structural concreting and serve as a better replacement for conventional coarse aggregate. ${ }^{6}$ It also proves to be cost effective and the production of such aggregates in bulk provides better economy.

Although concrete is regarded as a homogeneous material, it is actually a combination of a binder, fine aggregate, coarse aggregate, water and admixtures. Standardized concrete made of conventionally used raw materials is proportioned and produced in such a way that it makes the concrete, justifying the fact that it is homogeneous and it is known for its high compressive strength. However, the tensile strength is very low. ${ }^{7}$ In recent years basalt fibres are gaining importance for their excellent tensile properties and ductilities. ${ }^{8,9}$ The behaviour of concrete depends up on the type of fibre, its orientation, geometry and density. ${ }^{10}$

\subsection{Research significance}

From a literature review it is understood that the strength properties and structural behaviour of artificially manufactured lightweight aggregates cannot be the same everywhere. ${ }^{33}$ This is because these aggregates are manufactured from the raw materials obtained from the locality. For instance, sintered-fly-ash aggregates are manufactured from the basic raw material fly ash. The fly ash is obtained from thermal power plants and is regarded as one of the waste materials. The properties of fly ash depend up on its basic composition. This composition varies from place to place. Again, there is no standardization in the manufacturing process of artificial aggregates. Therefore, to develop an aggregate fit to be used as a coarse aggregate in concrete, a lot of admixtures are added and the material is subjected to heat treatments. This is the reason behind the varying properties of aggregates. After expanding the study, it was observed that a research gap still exists in developing a standardized procedure for batching, mixing and manufacturing the aggregates and there are no proper codal provisions for mix designing of the LWAC. The strength and durability properties of the lightweight aggregates that are factory made is greatly influenced by various factors, such as porosity, void ratio, sorptivity, water absorption, particle size, shape and texture, bonding characteristics, etc.

Although a lot of literature is available on alternative construction materials and the utilization of industrial by-products, the sintered-fly-ash aggregates are a better replacement for conventional coarse aggregate, and it also leads to a better evolution in the construction industry as well. ${ }^{32}$ But the lack of a standardized procedure on mix proportioning and durability of the lightweight aggregate concrete impresses the need to look at this aspect in a different manner. The usual test procedures have been analysed over decades and decades and from time to time. The improvements of these testing procedures need to be focused so that it has a direct effect on the properties of the concrete. The sintered-fly-ash aggregate concrete fails by cracking through the aggregates rather than failure along the cement matrices. An optimum $0.25 \%$ by weight of concrete of basalt fibre found through laboratory experiments is added to the concrete to study its specific tensile behaviour.

\section{EXPERIMENTAL PART}

The mix was designed to obtain a compressive strength of $(25,30$ and 40$) \mathrm{MPa}$ at $28 \mathrm{~d}$ of aging using IS 10262:2009. All the concrete mix was designed to be cohesive and workable. At least 10 specimens were cast for each mix so as to understand the quality of the concrete and to arrive at the empirical relationships among the mechanical properties of the mix. Prior to mechanical testing, non-destructive testing was carried out and the results were produced. ${ }^{6}$ After $28 \mathrm{~d}$ of water curing, durability tests were initiated. It was decided to carry out sorptivity tests and ponding tests since the aggregate was porous in nature. These experiments were carried out under controlled laboratory conditions. An empirical relation between the basic mechanical properties of the mix, the Young's modulus, the quality of

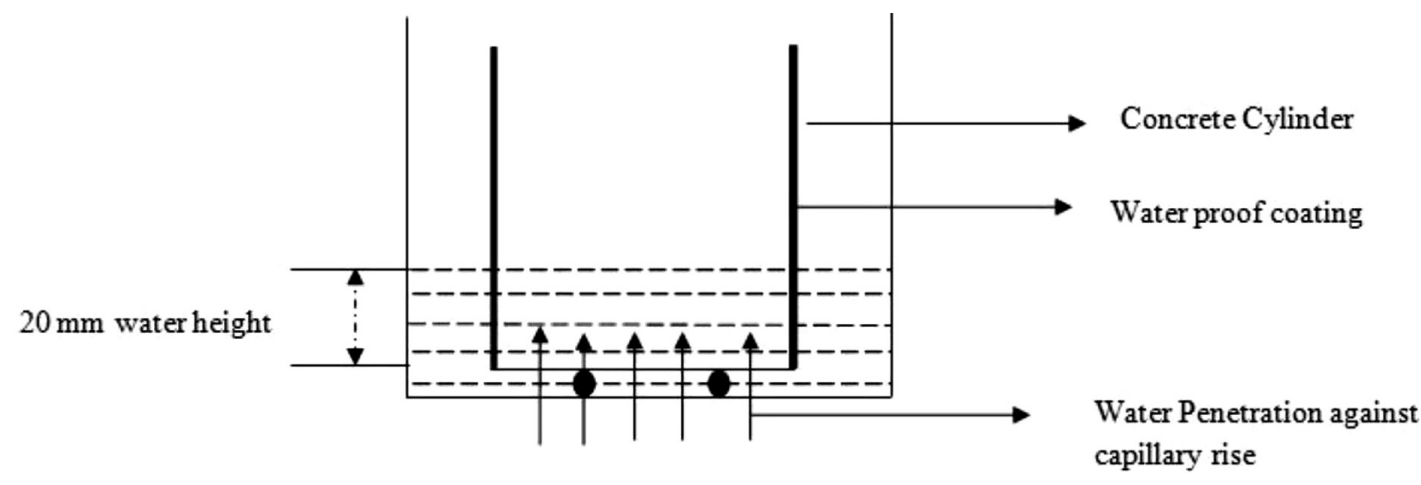

Figure 1: Sorptivity test setup 
Table 1: Details of mix proportioning

\begin{tabular}{|c|c|c|c|c|c|c|c|c|}
\hline \multirow[b]{2}{*}{ S. No. } & \multirow[b]{2}{*}{ Mix ID } & \multirow{2}{*}{$\begin{array}{l}\text { Grade of } \\
\text { concrete }\end{array}$} & \multicolumn{4}{|c|}{ Materials (kg) } & \multirow{2}{*}{$\begin{array}{l}\text { Volume } \\
\text { of SP } \\
(\%)\end{array}$} & \multirow[b]{2}{*}{$W / C$ ratio } \\
\hline & & & Cement & $\begin{array}{c}\text { Fine } \\
\text { aggregate }\end{array}$ & $\begin{array}{c}\text { Coarse } \\
\text { aggregate }\end{array}$ & Water & & \\
\hline 1. & NA & M25 & 358 & 828 & 1120 & 150 & 0.3 & 0.42 \\
\hline 2. & NAF & M25 & 358 & 828 & 1120 & 150 & 0.5 & 0.42 \\
\hline 3. & SA & M25 & 371 & 684 & 686 & 163 & 0.25 & 0.44 \\
\hline 4. & SAF & M25 & 371 & 684 & 686 & 163 & 0.35 & 0.44 \\
\hline 5. & NB & M30 & 382 & 795 & 1074 & 172 & 0.3 & 0.45 \\
\hline 6. & NBF & M30 & 382 & 795 & 1074 & 172 & 0.5 & 0.45 \\
\hline 7. & SB & M30 & 384 & 659 & 676 & 165 & 0.25 & 0.43 \\
\hline 8. & SBF & M30 & 384 & 659 & 676 & 165 & 0.4 & 0.43 \\
\hline 9. & $\mathrm{NC}$ & M40 & 429 & 685 & 1092 & 193 & 0.4 & 0.45 \\
\hline 10. & $\mathrm{NCF}$ & M40 & 429 & 685 & 1092 & 193 & 0.45 & 0.45 \\
\hline 11. & SC & M40 & 445 & 617 & 690 & 178 & 0.25 & 0.4 \\
\hline 12. & SCF & M40 & 445 & 617 & 690 & 178 & 0.3 & 0.4 \\
\hline
\end{tabular}

\begin{tabular}{|l|l|l|l|l|}
\hline Note: & $\begin{array}{l}\text { NA-Conventional concrete } \\
\text { of grade M25 }\end{array}$ & $\begin{array}{l}\text { NAF-Conventional concrete } \\
\text { with basalt fibre of grade } \\
\text { M25 }\end{array}$ & $\begin{array}{l}\text { SA- Sintered-fly-ash } \\
\text { aggregate concrete of grade } \\
\text { M25 }\end{array}$ & $\begin{array}{l}\text { SAF- Sintered-fly-ash } \\
\text { aggregate concrete with } \\
\text { basalt fibre of grade M25 }\end{array}$ \\
\hline $\begin{array}{l}\text { NB-Conventional concrete } \\
\text { of grade M30 }\end{array}$ & $\begin{array}{l}\text { NBF-Conventional concrete } \\
\text { with basalt fibre of grade } \\
\text { M30 }\end{array}$ & $\begin{array}{l}\text { SB- Sintered-fly-ash } \\
\text { aggregate concrete of grade } \\
\text { M30 }\end{array}$ & $\begin{array}{l}\text { SBF- Sintered-fly-ash } \\
\text { aggregate concrete with } \\
\text { basalt fibre of grade M30 }\end{array}$ \\
\hline $\begin{array}{c}\text { NC-Conventional concrete of } \\
\text { grade M40 }\end{array}$ & $\begin{array}{l}\text { NCF-Conventional concrete } \\
\text { with basalt fibre of grade } \\
\text { M40 }\end{array}$ & $\begin{array}{c}\text { SC- Sintered-fly-ash } \\
\text { aggregate concrete of grade } \\
\text { M40 }\end{array}$ & $\begin{array}{c}\text { SCF- Sintered-fly-ash } \\
\text { aggregate concrete with } \\
\text { basalt fibre of grade M40 }\end{array}$ \\
\hline
\end{tabular}

the concrete and the durability effects of the concrete in terms of sorptivity and ponding were carried out. It was observed through the sorptivity test, that it is possible to evaluate the void ratio, porosity and water absorption by applying the basic concepts of soil mechanics. The usual ponding test procedure involves salt ponding, but in this study an attempt was made to study the ponding test with water for a period of $24 \mathrm{~h}$. The sorptivity test involves a rise of the water against capillarity and the ponding test involved the rise of water towards the gravitational force. This proves to be a key for evaluating the structural behaviour in terms of durability, where the structure is subjected to weathering actions and problems arising due to the rise in water table, etc.

\subsection{Materials and mix proportioning}

Concretes of M25, M30 and M40 grades were used in the present study. It was proportioned in accordance with the Indian standard IS:10262 11 and given in Table 1. Ordinary Portland cement (OPC) of 53 grade conforming to IS:26912 was used. River sand of grading Zone II, specific gravity of 2.56 and fineness modulus of 2.79 conforming to IS: 383 was used. The coarse aggregates with a specific gravity of 2.72 , bulk density of $1625 \mathrm{~kg} / \mathrm{m}^{3}$ and water absorption of $0.9 \%$ were used for the conventional mix. ${ }^{13}$ The sintered-fly-ash aggregate was found to have a specific gravity of 1.42 , a bulk density of $890 \mathrm{~kg} / \mathrm{m}^{3}$ and a water absorption of $15.6 \%$. A polycarboxlate-based superplasticizer conforming to IS: $9103^{14}$ was used to increase the workability of the concrete. An optimum of $0.25 \%$ of chopped basalt fibre strands of length $18 \mathrm{~mm}$ with a tensile strength of 4150 MPa were used.

\subsection{Testing of specimens}

The 28-days water-cured concrete specimens were tested for compression, split tension and flexure as per Indian standard IS:516-1959. ${ }^{15}$ Prior to mechanical testing, the concrete cube samples were subjected to non-destructive testing. The ultrasonic pulse velocity test

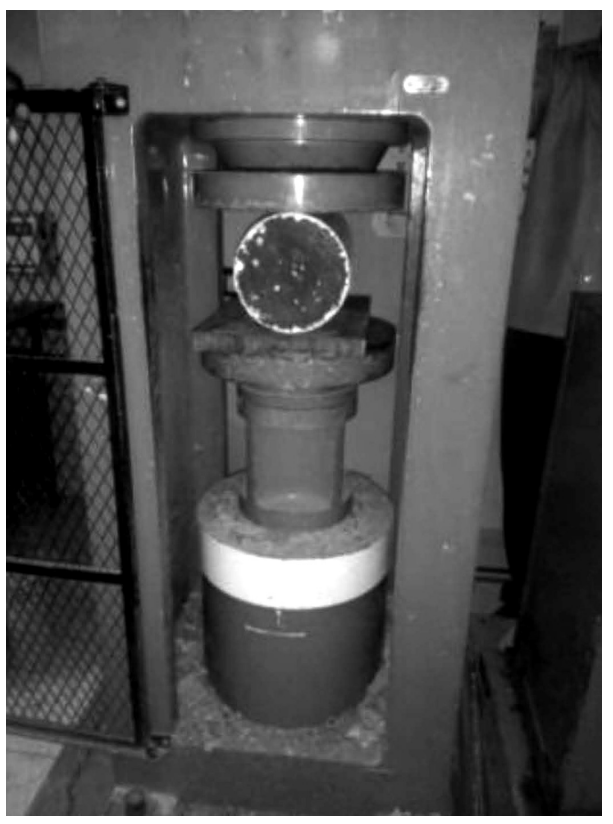

Figure 2: Splitting of SPECIMEN after $24 \mathrm{~h}$ 


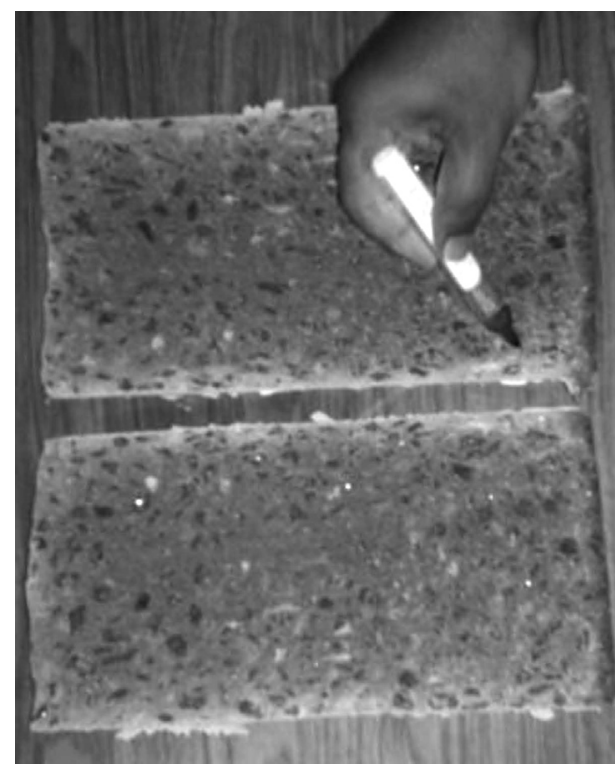

Figure 3: Water penetration plot

with direct transmission was made as per IS:13311 (Part 1): $1992^{16}$ and the rebound hammer test were performed as per IS:13311(Part 2):1992. ${ }^{17}$ The modulus of elasticity was found as per ASTMC469-10.18 The durability tests were performed as per the durability standards specified in ASTM C1585-13.19

The sorptivity test was conducted with a cylinder of height $300 \mathrm{~mm}$ and diameter $150 \mathrm{~mm}$. The specimens were cast and cured for a period of 28 days and tested $5 \mathrm{~d}$ after the curing period. After curing, the test specimens were dried in a hot-air oven at $100{ }^{\circ} \mathrm{C}$ for $24 \mathrm{~h}$ and allowed to cool. After cooling, the sides of the specimens were sealed properly with a non-absorbent coating so that there is no ingress of water through the sides of the cylinder, but the top and bottom of the cylinder are left free so as to ensure the flow of water against capillary rise through the pores of the cylinder. Initial weights of the entire specimen were taken. The test consisted of a bottom tray over which two steel rods were placed for resting the concrete cylinder. This setup enhances water absorption against capillary rise, which is the key concept of the sorptivity test. Time is noted from which

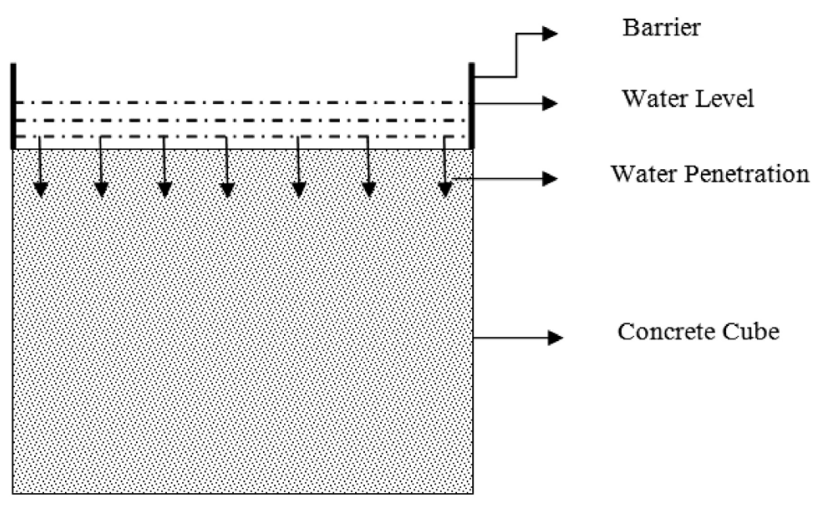

Figure 4: Ponding test setup

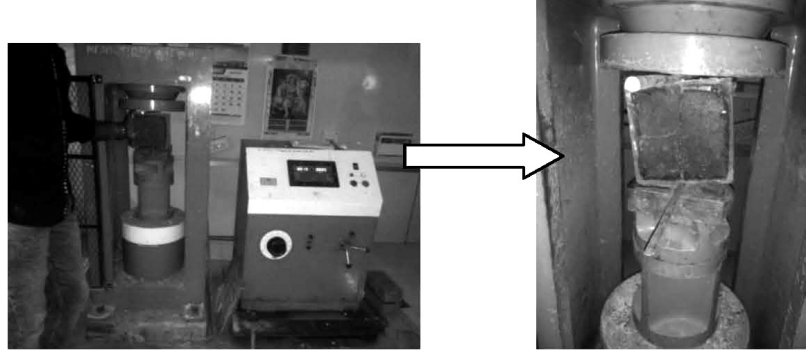

Figure 5: Splitting of specimen after $24 \mathrm{~h}$

water is added to the tray till $24 \mathrm{~h}$. The water level was maintained in such a way that the water is at least $1 \mathrm{~cm}$ above the base of the cylinder. The test as performed is shown in Figure 1. The initial weight of the cylinder was noted and then the weight of the cylinder was noted for various time differences up to $24 \mathrm{~h}$. At the end of $24 \mathrm{~h}$, the cylinder is split into two halves, as shown in Figures $\mathbf{2}$ and $\mathbf{3}$, and the water-absorption pattern is noted down with no time delay.

The ponding test was made on concrete cubes $(150 \mathrm{~mm} \times 150 \mathrm{~mm})$ at the age of $28 \mathrm{~d}$, where the test specimens were dried in a hot-air oven at $100{ }^{\circ} \mathrm{C}$ for $24 \mathrm{~h}$ and allowed to cool to room temperature. After cooling, a pond-like setup, as shown in Figure 4, was made on the top of the cube over a height of $30 \mathrm{~mm}$. Proper care is taken that there is no leakage from the sealed ponds. The initial weight of the specimen was noted. Water is poured over a height of $25 \mathrm{~mm}$ and left for $24 \mathrm{~h}$ and finally, the weight is noted down. To observe the water absorption pattern inside the cube, the cube is split into two halves, as shown in Figures 5 and $\mathbf{6}$ with no time delay.

\section{TEST RESULTS AND DISCUSSION}

\subsection{Rebound hammer test}

From the rebound hammer test, the compressive strengths of concrete specimens were accessed, based on the correlation between the rebound index and the compressive strength. The rebound hammer test is indicative

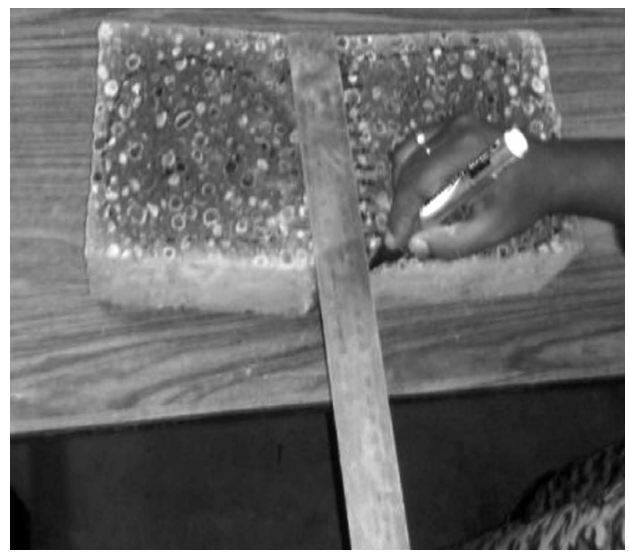

Figure 6: Water absorption plot 
of the surface hardness of the concrete. The better is the hardness, the higher is the quality of the concrete. Table 2 indicates that the hardness and strength of concrete varies with respect to the age of the concrete. ${ }^{17}$ The rebound number is found to increase with an increase in the compressive strength. The rebound hammer test can be used to study the uniformity of the concrete, ${ }^{20}$ not the strength, but justification can be given when complemented with destructive tests.

Table 2: Compressive strength and quality of concrete from rebound hammer test

\begin{tabular}{|c|c|c|c|c|}
\hline S1. No & Mix ID & $\begin{array}{c}\text { Average } \\
\text { compressive } \\
\text { strength }\end{array}$ & $\begin{array}{c}\text { Rebound } \\
\text { number }\end{array}$ & $\begin{array}{c}\text { Quality of } \\
\text { concrete }\end{array}$ \\
\hline 1 & NA & 21.4 & 25 & Fair \\
\hline 2 & NAF & 25.6 & 27 & Fair \\
\hline 3 & SA & 23.7 & 26 & Fair \\
\hline 4 & SAF & 26.8 & 28 & Fair \\
\hline 5 & NB & 36.35 & 39 & Good layer \\
\hline 6 & NBF & 40.68 & 42 & $\begin{array}{c}\text { Very good } \\
\text { hard layer }\end{array}$ \\
\hline 7 & SB & 38.68 & 40 & Good layer \\
\hline 8 & SBF & 40.7 & 43 & $\begin{array}{c}\text { Very good } \\
\text { hard layer }\end{array}$ \\
\hline 9 & NC & 43.6 & 45 & $\begin{array}{c}\text { Very good } \\
\text { hard layer }\end{array}$ \\
\hline 10 & NCF & 45.5 & 47 & $\begin{array}{c}\text { Very good } \\
\text { hard layer }\end{array}$ \\
\hline 11 & SC & 43.4 & 45 & $\begin{array}{c}\text { Very good } \\
\text { hard layer }\end{array}$ \\
\hline 12 & SCF & 44.68 & 46 & $\begin{array}{c}\text { Very good } \\
\text { hard layer }\end{array}$ \\
\hline
\end{tabular}

\subsection{Ultrasonic-pulse velocity test}

From the ultrasonic pulse velocity test (Table 3), the conventional concrete proved to be homogeneous, indicating a better concrete, but the concrete with sinteredfly-ash aggregate was identified with medium quality. This is due to the presence of voids in the porous aggregate and accounting for the low density of the concrete. ${ }^{16}$ The density of the concrete found through the correlation was similar to that found through in other laboratory experiments. The Young's modulus $\left(E_{\mathrm{c}}\right)$ obtained from the laboratory testing and the dynamic

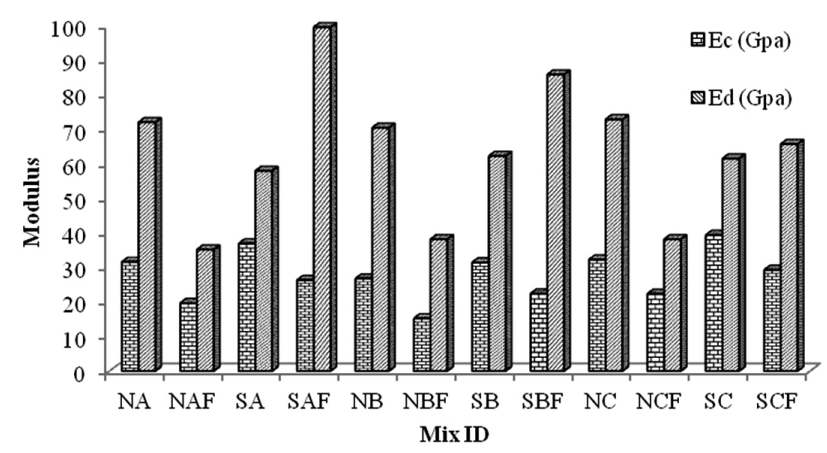

Figure 7: Plot on modulus of concrete modulus $\left(E_{\mathrm{d}}\right)$ of concrete ${ }^{16}$ is compared in Figure 7. The dynamic modulus is almost three times higher than the Young's modulus of the concrete. The dynamic modulus varies linearly with respect to the elastic modulus of the concrete. $^{21}$

Table 3: Inference from ultrasonic pulse velocity testing

\begin{tabular}{|c|c|c|c|c|}
\hline SI No & Mix ID & $\begin{array}{c}\text { Pulse velocity } \\
(\mathrm{km} / \mathrm{Sec})\end{array}$ & $\begin{array}{c}\text { Quality of } \\
\text { concrete }\end{array}$ & $\begin{array}{c}\text { Density } \\
\left(\mathrm{kg} / \mathrm{m}^{3}\right)\end{array}$ \\
\hline 1 & NA & 4.11 & Good & 2524.6 \\
\hline 2 & NAF & 4.37 & Good & 1954.4 \\
\hline 3 & SA & 3.02 & Medium & 2546.6 \\
\hline 4 & SAF & 3.04 & Medium & 1967.2 \\
\hline 5 & NB & $4 . .2$ & Good & 2570.9 \\
\hline 6 & NBF & 4.31 & Good & 1974 \\
\hline 7 & SB & 3.1 & Medium & 2590.5 \\
\hline 8 & SBF & 3.14 & Medium & 1983.1 \\
\hline 9 & NC & 4 & Good & 2590.2 \\
\hline 10 & NCF & 4.2 & Good & 1979.4 \\
\hline 11 & SC & 3.08 & Medium & 2601 \\
\hline 12 & SCF & 3.4 & Medium & 1989 \\
\hline
\end{tabular}

\subsection{Mechanical properties}

Initially, the slump of the mix was checked prior to the mechanical testing. The use of fibres affected the workability and flowability of the plain concrete intrinsically. ${ }^{22}$ The addition of superplasticizer in the mix, improved the workability of the mix..$^{23,24}$ The conventional concrete obtained a slump range of $80-100 \mathrm{~mm}$, but the slump of sintered-fly-ash aggregate concrete ranged from $50 \mathrm{~mm}$ to $65 \mathrm{~mm}$. The sintered-fly-ash aggregate concrete is proportioned in such a way that it has similar compressive strength as the conventional mix. The addition of fibre to the mix increased the compressive strength of the conventional mix to $15.2 \%$ and the sintered-fly-ash aggregate concrete to $16.6 \%$. The split tensile strength was found to be higher by $8.7 \%$ sintered-fly-ash aggregate concrete, $30.6 \%$ higher for conventional concrete with basalt fibre, $46.2 \%$ higher for sintered-fly-ash aggregate concrete with basalt fibre

Table 4: Mechanical properties at the age of $28 \mathrm{~d}$

\begin{tabular}{|c|c|c|c|c|}
\hline Sl. No. & $\begin{array}{c}\text { Mix } \\
\text { ID }\end{array}$ & $\begin{array}{c}\text { Cube com- } \\
\text { pressive } \\
\text { strength (MPa) }\end{array}$ & $\begin{array}{c}\text { Flexural } \\
\text { strength } \\
(\mathrm{MPa})\end{array}$ & $\begin{array}{c}\text { Splitting } \\
\text { tensile strength } \\
(\mathrm{MPa})\end{array}$ \\
\hline 1 & NA & 33.82 & 4.81 & 4.02 \\
\hline 2 & SA & 33.38 & 6.28 & 4.15 \\
\hline 3 & NAF & 38.96 & 5.23 & 4.51 \\
\hline 4 & SAF & 39.44 & 7.03 & 4.86 \\
\hline 5 & NB & 38.04 & 4.22 & 4.00 \\
\hline 6 & SB & 38.62 & 6.86 & 4.17 \\
\hline 7 & NBF & 42.56 & 5.32 & 4.68 \\
\hline 8 & SBF & 42.88 & 7.98 & 5.20 \\
\hline 9 & NC & 49.06 & 4.67 & 4.53 \\
\hline 10 & SC & 50.58 & 6.36 & 5.01 \\
\hline 11 & NCF & 54.02 & 5.52 & 5.01 \\
\hline 12 & SCF & 55.72 & 7.30 & 5.19 \\
\hline
\end{tabular}


when compared with the conventional mix. The flexural strength was found to be $12.2 \%$ higher for sintered-flyash aggregate concrete, $3.2 \%$ higher for conventional concrete with basalt fibre, $21 \%$ higher for sintered-flyash aggregate concrete with basalt fibre when compared with the conventional mix. The mechanical properties determined at $28 \mathrm{~d}$ of ageing are shown in Table 4.

\subsection{Stress-strain curve}

In theoretical applications, the concrete is assumed to be elastic, isotropic, and homogeneous and it obeys Hooke's law. But in practical cases it is not possible. The concrete is not perfectly elastic or isotropic or homogeneous. The response of concrete to loading is quite complex. Therefore, in order to evaluate the response of the concrete to loading, the compression stress-strain test is carried out for a cylindrical specimen. The typical stress-strain relationship of M30 grade concrete is shown in Figure 8. The curve thus obtained by testing revealed the concrete is of medium strength; as low strength concrete will have a deep curve and for high strength concrete, it will not be much curved. ${ }^{20}$

The secant modulus of the stress strain curve for each mix was found and it was taken as the Young's modulus of the concrete. It can be noted from Figure 9 that the sintered-fly-ash aggregate concrete has a lower modulus of elasticity; however, the normal weight concrete has a

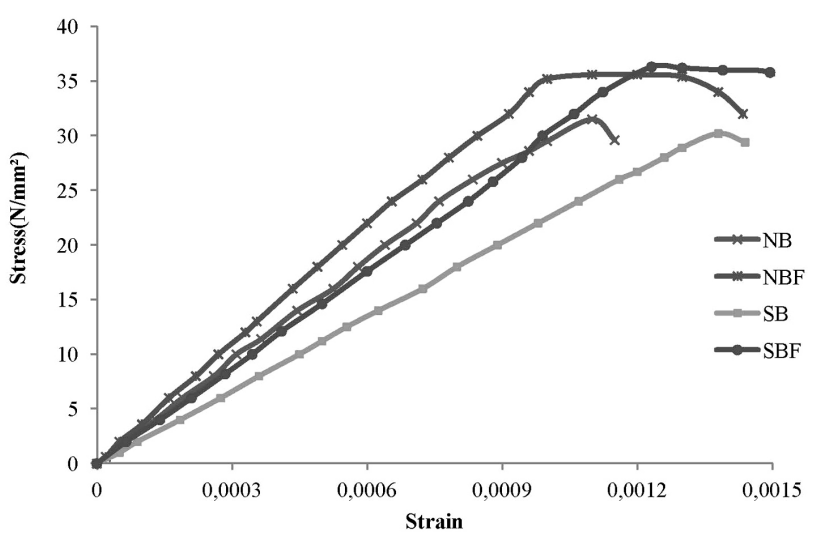

Figure 8: Typical stress-strain curve for concrete

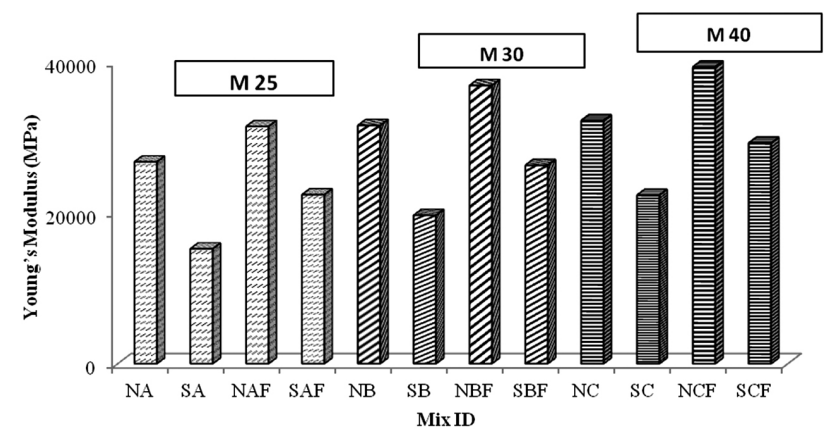

Figure 9: Young's modulus of concrete comparatively higher Young's modulus, which in turn was increased by the addition of basalt fibre. ${ }^{25}$ This can be easily justified by the fact that a dense aggregate led to a high value of Young's modulus in concrete. Sintered-fly-ash aggregate, being a porous aggregate by nature, leads to less dense concrete, which directly reduces the Young's modulus in concrete. ${ }^{26}$ Also, a higher value of Young's modulus can be obtained if a larger portion of coarse aggregate is used and if basalt fibre is added to the mix.

\subsection{Relationship between compression, split flexural strength and Young's modulus of concrete mix and regression analysis}

In reinforced-concrete construction, more importance is given only for the strength of the concrete in compression. But the tensile and flexural capacity of concrete has to be found to know the capacity of the concrete under direct tension. It can be directly found through experiments or through relations developed in accordance with the compressive strength of the concrete. The ratio of the strengths depends up on the general level of strength of the concrete.

These relationships are influenced by the bond strength between the cement paste and aggregate bonding. With improper curing and inferior quality of the $\mathrm{C}-\mathrm{S}-\mathrm{H}$ gel formation, the tensile strength is greatly affected. The relationships so developed can be used during theoretical and analytical investigations of concrete.

Although a lot of statistical models are available for the prediction of the strength parameters of concrete, a regression analysis proves to be one of the most effective tools in the prediction of concrete models. In this experiment, an attempt was made to achieve the empirical relation shown in Table 5 between the mechanical aspects of concrete based on experimental investigation carried out on a concrete sample. The relationship shows

Table 5: Empirical equations relating the mechanical properties of concrete

\begin{tabular}{|c|c|c|c|}
\hline S1. no. & Mix ID & Empirical equations & $R^{2}$ \\
\hline \multicolumn{4}{|c|}{ Relation between compressive strength split tensile strength } \\
\hline 1 & NA & $f_{\mathrm{r}}=0.111 f_{\mathrm{ck}}-0.219$ & 0.899 \\
\hline 2 & NAF & $f_{\mathrm{r}}=0.061 f_{\mathrm{ck}}+2.059$ & 0.803 \\
\hline 3 & SA & $f_{\mathrm{r}}=0.265 f_{\mathrm{ck}}-5.992$ & 0.943 \\
\hline 4 & SAF & $f_{\mathrm{r}}=0.100 f_{\mathrm{ck}}+0.311$ & 0.891 \\
\hline \multicolumn{4}{|c|}{ Relation between compressive strength and flexural strength } \\
\hline 5 & NA & $f_{\mathrm{cr}}=0.305 f_{\mathrm{ck}}-6.411$ & 0.927 \\
\hline 6 & NAF & $f_{\mathrm{cr}}=0.361 f_{\mathrm{ck}}-5.058$ & 0.910 \\
\hline 7 & SA & $f_{\mathrm{cr}}=0.673 f_{\mathrm{ck}}-19.03$ & 0.945 \\
\hline 8 & SAF & $f_{\mathrm{cr}}=0.409 f_{\mathrm{ck}}-7.940$ & 0.889 \\
\hline \multicolumn{4}{|c|}{ Relation between split tensile strength and flexural strength } \\
\hline 9 & NA & $f_{\mathrm{r}}=0.348 f_{\mathrm{cr}}+2.188$ & 0.890 \\
\hline 10 & NAF & $f_{\mathrm{r}}=0.171 f_{\mathrm{cr}}+2.905$ & 0.897 \\
\hline 11 & SA & $f_{\mathrm{r}}=0.371 f_{\mathrm{cr}}+1.649$ & 0.889 \\
\hline 12 & SAF & $f_{\mathrm{r}}=0.223 f_{\mathrm{cr}}+2.526$ & 0.830 \\
\hline
\end{tabular}




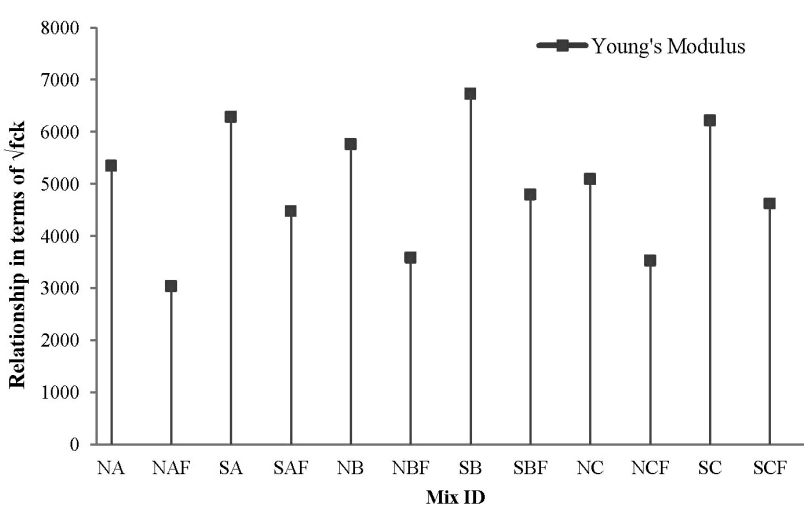

Figure 10: Relationship between $\sqrt{f_{\mathrm{ck}}}$ and $E_{\mathrm{c}}$

linear empirical relations and the $R^{2}$ values were approximately $90 \%$, thus proving the correctness of the sampling. ${ }^{27}$ Figure 10 provides the relationship between Young's modulus and the compressive strength of the concrete. The relationship between the dynamic modulus of elasticity and the compressive strength of the cube increases with an increase in the concrete strength and the equation is found to fit the observed result. ${ }^{28}$ The addition of basalt fibre to the concrete affects the Young's modulus considerably, irrespective of the nature of concrete. However, compared to normal-weight concrete, the lightweight concrete has an increased Young's modulus.

\subsection{Durability properties}

\subsubsection{Sorptivity}

Sorptivity ( $\mathrm{S}$ ) is a material property that characterizes the tendency of a porous material to absorb and transmit water by capillarity. ${ }^{29}$ The cumulative water absorption (per unit area of the inflow surface) with respect to elapsed time (t) is calculated and the results are shown in Figure 11. An increased rate of sorptivity was observed in the initial stages, which decreased gradually over time. ${ }^{30}$ The lightweight concrete responded with increased sorptivity when compared to the normal weight concrete. As per the acceptance limit for the durability indexes, ${ }^{31}$ the acceptance criteria for sorptivity in $\mathrm{mm} / \mathrm{hr}$ for laboratory concrete should be less than 6 after $24 \mathrm{~h}$ of observation. The test results were within the acceptable

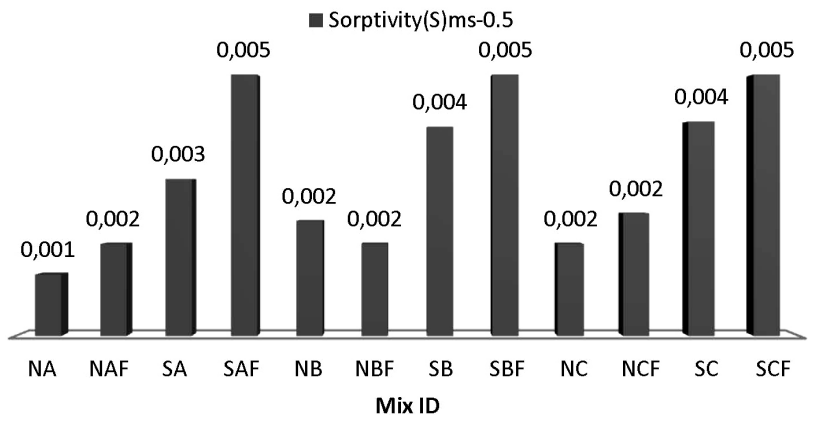

Figure 11: Sorptivity (S) of concrete mix at $24 \mathrm{~h}$

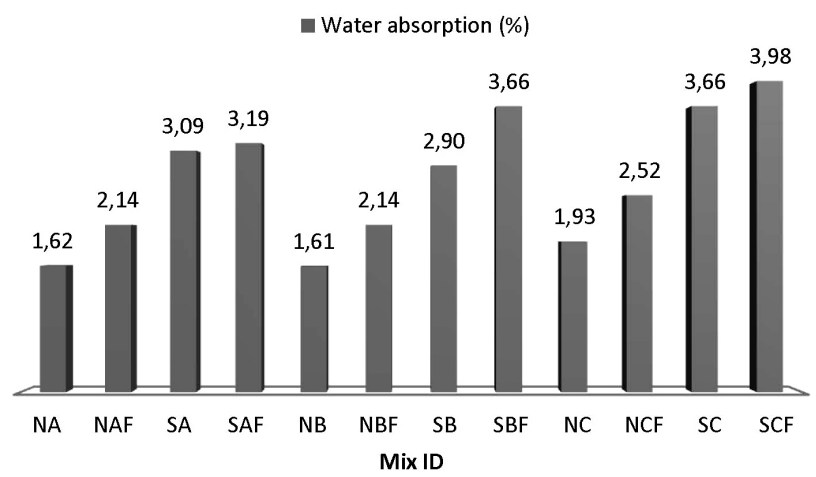

Figure 12: Water absorption (\%) of concrete mix at $24 \mathrm{~h}$

limits, indicating that the concrete is durable in terms of sorptivity.

\subsubsection{Water absorption}

Water absorption of the concrete mix was calculated during $24 \mathrm{~h}$ of observation, as shown in Figure 12. The sintered-fly-ash aggregates showed almost $16 \%$ water absorption, but as a matrix inside the concrete, the rate of water absorption is very low. This means that the lightweight concrete averaged in durability behaviour.

\subsubsection{Water absorption per unit area of inflow surface}

Water absorption per unit area of Inflow surface is calculated from the sorptivity test in order to find out how the pores in the concrete affect the water-absorption characteristics. Owing to the porous nature of the aggregates, the water absorption per unit area of the inflow surface of the lightweight concrete is comparatively high. In contrast, the inclusion of fibre increases the mechanical properties, but it had no effect on reducing the porosity of the concrete. Further, these fibres indirectly induced more water absorption. The test results are shown in Figure 13.

\subsubsection{Porosity}

The presence of voids in lightweight concrete can be filled with air or with water. It is known that the more porous the concrete, the weaker it will be. However, the mix was proportioned in such a way that it had similar

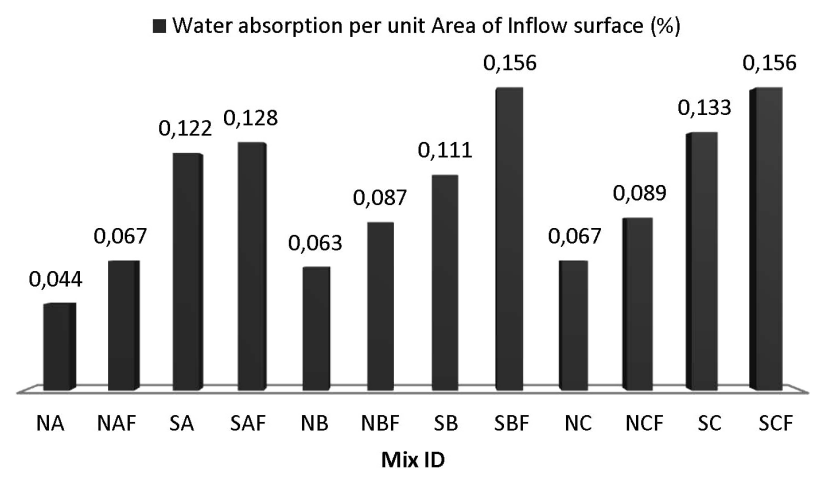

Figure 13: Water absorption per unit area of inflow surface (\%) of concrete mix at $24 \mathrm{~h}$ 


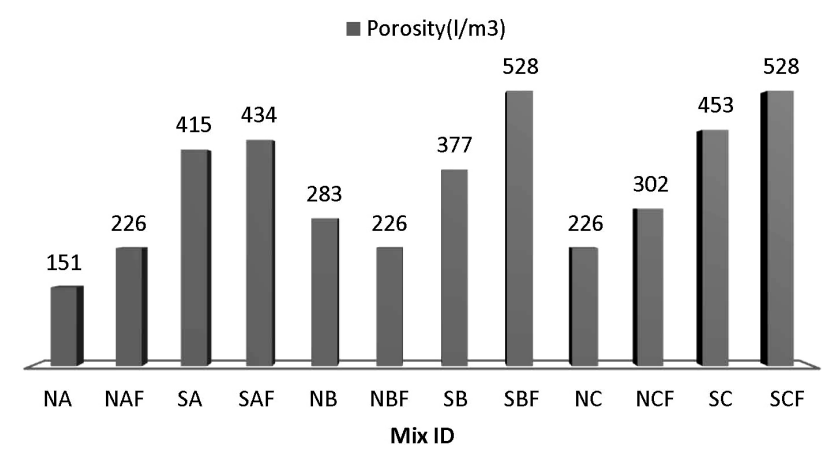

Figure 14: Porosity of concrete mix at $24 \mathrm{~h}$

strength as the conventional material. The porosity of the concrete with respect to sorptivity is calculated and shown in Figure 14. The porosity of lightweight concrete and fibre-reinforced concrete was found to be more than the conventional. This may be due to the difference in water-cement ratio of the mix that affects the porosity considerably. The integrity of the paste-aggregate bond is critical. If there is no bond, the aggregate effectively represents a void that creates a zone of weakness in the concrete. It also represents a weak IZ zone. The durability test results indicate that these values are in the acceptable range for the construction of a durable concrete structure; however, they are lower than that of conventional-weight concrete. ${ }^{31}$

The saturated density of the mix found through the sorptivity test is found to be exactly matching that found with a simple laboratory experiment. Then, an attempt was made to track the pattern of the water penetration against the capillary rise by splitting the specimen into two halves. The void ratio of the concrete specimen was arrived through this method. From the pattern of the absorbed water, as shown in Figure 15, recorded immediately before the water evaporation, it was found that the concrete made of sintered-fly-ash aggregate with and without fibre inclusion showed almost full absorption of the water at the middle length when compared to the conventional, irrespective of the grade of the concrete. The aggregates being porous in nature, lead to this

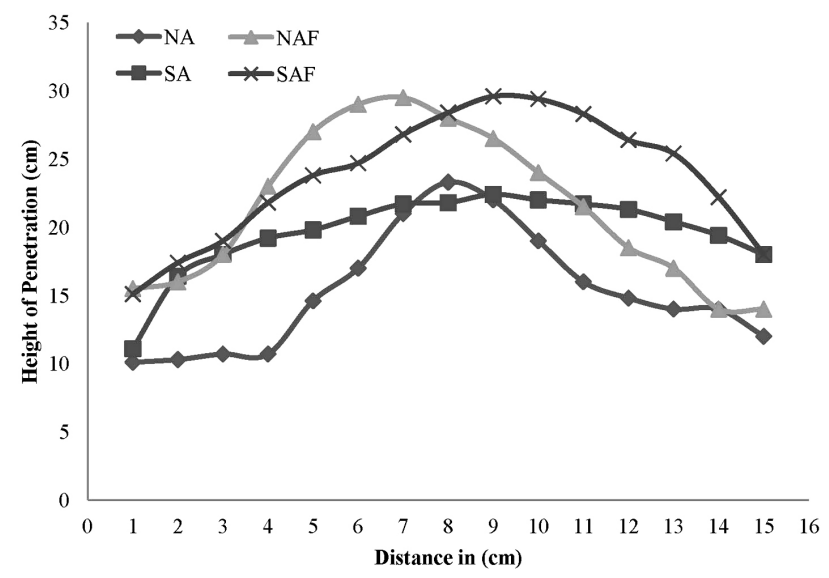

Figure 15: Water penetration plot on sorptivity test

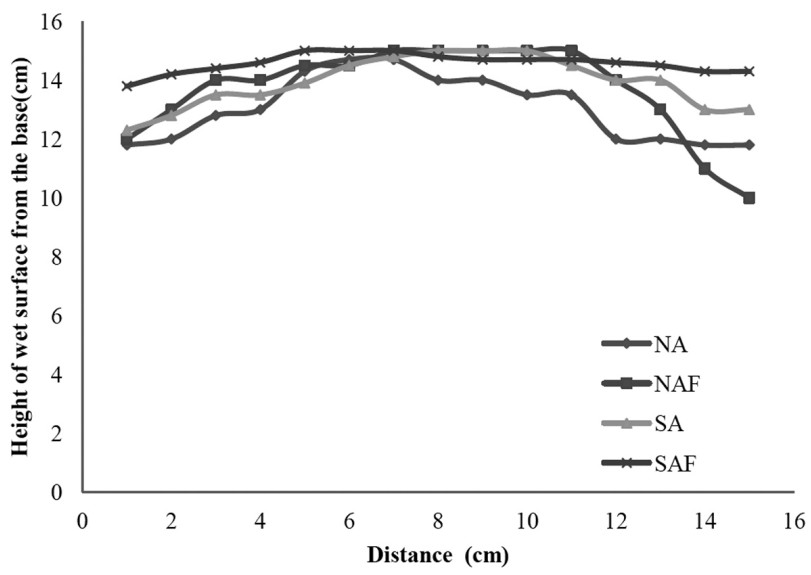

Figure 16: Water penetration plot on ponding test

effect. It may cause corrosion and other associated problems when not adhering strictly to the quality requirements of the concrete. From this evaluation, the void ratio of concrete was found.

\subsubsection{Ponding test}

The ponding test was conducted to evaluate the void ratio and validate the sorptivity characteristics of the concrete towards the gravitational force. This condition of testing was achieved by splitting the concrete cube specimen after $24 \mathrm{~h}$ of observation and the pattern of water penetration was observed, as shown in Figure 16. Obviously, almost all the concrete specimens, irrespective of the grade of concrete, showed complete absorption of the water, as all the objects (including liquid) tends to move towards gravity. The difference was the percentage of water absorption among the different variables in the concrete. The sintered-fly-ash aggregate concrete proved to have highest water-penetration rate.

Codal provisions, such as minimum cement content, maximum water-cement ratio, concrete cover to the reinforcement, etc., must be more strict than that of normal-weight aggregate concrete to ensure a similar level of durability under the same exposure conditions.

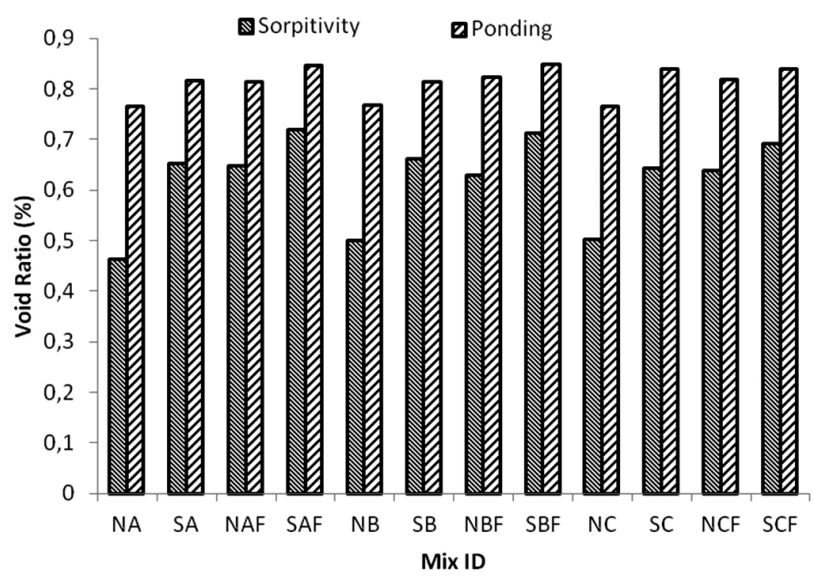

Figure 17: Comparision of void ratio 


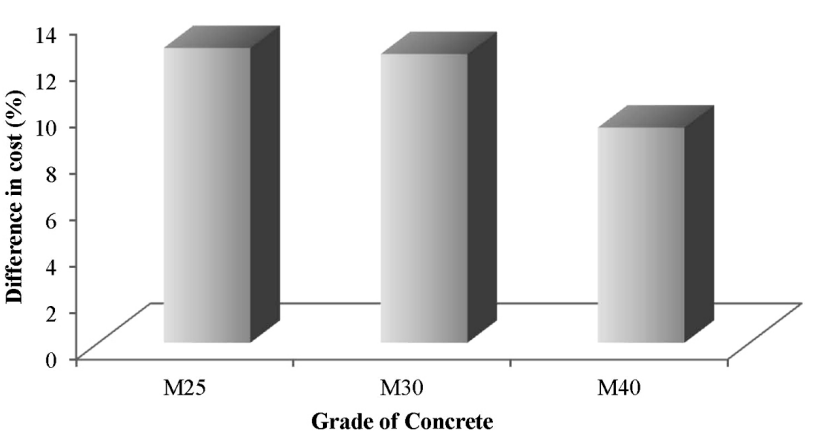

Figure 18: Cost analysis of concrete

These aggregates, when used in structural elements, will be subjected to water stagnation or the nearby water sources through the ground, penetrating into the structure. These effects can be studied by subjecting the concrete to water-penetration tests. The sorptivity and ponding tests can serve as a key element in determining the flow of water towards gravity and through capillary rise. On comparing, the water absorption percentage of the mix subjected to sorptivity and ponding, there was no significant large variations in the observation, although both these tests are of opposite nature.

From the water-penetration plot of sorptivity and porosity, the void ratio of the mix is calculated and shown in Figure 17. Although there are no proper procedures to find the void ratio of the concrete, an attempt has been made to find the void ratio by understanding the basics of soil mechanics. The void ratio found through sorptivity is almost $3 / 4$ times less than that found through ponding. The difference is caused by the nature of gravity. Fluid flows freely towards gravity and it takes time to rise against gravity. This would be the reason for such a difference in void ratio of the mix.

\section{COST ANALYSIS}

The cost difference in Figure $\mathbf{1 8}$ denotes that the use of sintered-fly-ash aggregate in concrete considerably reduces the cost of the concrete. The cost analysis is carried out based on local rates available on the market. Since the sintered-fly-ash aggregate is made from an industrial by-product, fly ash, which is regarded as a waste material, if attempts were made to produce aggregates of this type with many other waste materials too, and commercialize the solution, it would lead to the development of large-scale industrialization, which further reduces the cost of production, which in turn effects the construction cost. Therefore, the bulk production of such aggregates will be a better solution for waste disposal and associated problems, thus creating job opportunities and preserving nature from the quarrying of mountains.

\section{CONCLUSIONS}

From the experimental study, the following conclusions can be drawn:

- The slump value of the sintered-fly-ash aggregate concrete is $50-65 \mathrm{~mm}$, whereas the conventional mix had a slump range of $80-100 \mathrm{~mm}$ for each grade of concrete.

- The compressive strength of basalt-fibre-reinforced conventional mix was $15.2 \%$ and basalt-fibre-reinforced sintered-fly-ash aggregate concrete was $16.6 \%$ more than the conventional.

- The split tensile strength was found to be higher by $8.7 \%$ for sintered-fly-ash aggregate concrete, $30.6 \%$ higher for conventional concrete with basalt fibre, $46.2 \%$ high for sintered-fly-ash aggregate concrete with basalt fibre when compared with the conventional mix.

- The flexural strength was found to be $12.2 \%$ higher for sintered-fly-ash aggregate concrete, $3.2 \%$ higher for conventional concrete with basalt fibre, $21 \%$ higher for sintered-fly-ash aggregate concrete with basalt fibre when compared with the conventional mix.

- The Young's modulus of the sintered-fly-ash aggregate concrete was found to be considerably lower than that of the conventional. However, the addition of basalt fibre increased the Young's modulus.

- The sorptivity and void ratio values of the sintered fly-ash-aggregate concrete was found to be higher than that of the conventional, owing to its porous nature.

- The sintered-fly-ash aggregate concrete has increased porosity, which is not desirable for making structural concrete. The effect can be reduced by using latexmodified sintered-fly-ash aggregate in concrete, since it arrests the pores considerably.

- The cost of sintered-fly-ash aggregate concrete is reduced considerably, by about $12 \%$ when compared to conventional concrete.

\section{Acknowledgment}

The work reported in this paper is a part of $\mathrm{PhD}$ project conducted at the Advanced Concrete Laboratory in the Department of Civil Engineering (S) at Government College of Technology, Coimbatore, India. The support extended by the faculty members, technicians and co-research scholars is greatly appreciated.

\section{REFERENCES}

${ }^{1}$ J. M. Khatib, Sustainability of construction materials, Woodhead publishing series in Civil and Structural Engineering, United Kingdom, 2016

${ }^{2}$ M. N. Haque, H. Al-Khaiat, O. Kayali, Strength and durability of lightweight concrete , Cement \& Concrete Composites, 26 (2004), 307-314, doi:10.1016/S0958-9465(02)00141-5 
${ }^{3}$ R. Prakash, R. Thenmozhi, S. N. Raman, C. Subramanian, Characterization of eco-friendly steel fiber reinforced concrete containing waste coconut shell as coarse aggregates and fly ash as partial cement replacement, (2019), 1-11, doi:10.1002/suco.201800355

${ }^{4}$ M. Aslam, P. Shafigh, Z. Jumaat, structural lightweight aggregate concrete by incorporating solid wastes as coarse lightweight aggregate, Applied Mechanics and Materials, 749 (2015), 337-342, doi:10.4028/www.scientific.net/AMM.749.337

${ }^{5}$ A. Sivakumar, P. Gomathi, Pelletized fly ash lightweight aggregate concrete: A promising material, Journal of Civil Engineering and Construction Technology, 3 (2012) 2, 42-8, doi:10.5897/ JCECT11.088

${ }^{6}$ J. L. Clarke, Structural Lightweight Aggregate Concrete, CRC Press, Taylor and Francis Group, 1993

${ }^{7}$ J. Branston, S. Das, S. Y. Kenno, C. Taylor, Mechanical behaviour of basalt fibre reinforced concrete. Construction and Building Materials, (2016),124, 878-886, doi:10.1016/j.conbuildmat.2016.08.009 ${ }^{8}$ M. E. Arslan, Effects of basalt and glass chopped fibres addition on fracture energy and mechanical properties of ordinary concrete: CMOD measurement. Construction and Building Materials, (2016), 114, 383-391, doi:10.1016/j.conbuildmat.2016.03.176

${ }^{9}$ S. K. Kirthika, S. K. Singh, experimental investigations on basalt fibre-reinforced concrete, Journal of Institution of Engineers, India, 99 (2018) 4, 661-670, doi:10.1007/s40030-018-0325-4

${ }^{10}$ Cory High, Hatem M. Seliem, Adel El-Safty, Sami H. Rizkalla, Use of basalt fibers for concrete structures,Construction and Building Materials, (2015), 96,37-46, doi:10.1016/j.conbuildmat.2015.07.138

${ }^{11}$ IS: 10262, Concrete mix proportioning-guidelines,Bureau of Indian Standards, 2009, New Delhi, India

${ }^{12}$ IS: 269,53 Grade Ordinary Portland cement: specifications, Bureau of Indian Standards 2015, New Delhi, India

${ }^{13}$ IS: 383 , Specification for coarse and fine aggregates from natural sources for concrete,Bureau of Indian Standards, (2016), New Delhi, India.

${ }^{14}$ IS: 9103 , Concrete admixtures-specifications. Bureau of Indian Standards, (1999), New Delhi, India

${ }^{15}$ IS: 516 - 1959, Methods of tests for strength of concrete, Bureau of Indian Standards, New Delhi, India

${ }^{16}$ IS 13311(Part 1): 1992, Indian Standard for Non-Destructive testing of Concrete, Methods of test-Part 1- Ultrasonic Pulse velocity

${ }^{17}$ IS 13311(Part 2): 1992, Indian Standard for Non-Destructive testing of Concrete, Methods of test-Part 2- Rebound Hammer

${ }^{18}$ ASTMC469-10, Standard Test Method for Static Modulus of Elasticity and Poisson's Ratio of Concrete in Compression

${ }^{19}$ ASTM C1585 - 13, Standard Test Method for Measurement of Rate of Absorption of Water by Hydraulic-Cement Concretes
${ }^{20}$ A. M. Neville, J. J. Brooks, Concrete technology, Pearson Education Asia Pvt Ltd, 2008,Kuala Lumpur

${ }^{21}$ P.-C. Aitcin, High Performance Concrete, CRC Press, Taylor and Francis Group 1998, London

${ }^{22}$ N. A. Memon, Sumadi, M. S. R. Ramli, Performance of high wokability slag-cement mortar for ferrocement,Building and Environment, 42 (2007) 7, 2710-2717, doi:10.1016/j.buildenv.2006. 07.015

${ }^{23}$ G. Lu, K. Wang, T. J. Rudolphi, Modeling rheological behavior of highly flowable mortar using concepts of particle and fluid mechanics, Cement and Concrete Composites, 302008 1, 1-12, doi:10.1016/j.cemconcomp.2007.06.002

${ }^{24}$ E. T. Dawood, M. Ramli, Flowable high-strength system as repair material, Structural Concrete, 11 (2010), 4, 199-209, doi:10.1680/ stco.2010.11.4.199

${ }^{25}$ Y. Haryanto, A. Widyaningrum, G. Heri Sudibyo, A. Maryoto, Mechanical properties of lightweight aggregate concrete reinforced with soda can waste fibre, MATEC Web of Conferences, 2017138, 01021, doi:10.1051/matecconf/201713801021

${ }^{26}$ X. Liu, J. Kong, Experimental Study of Stress-Strain Curves of Lightweight Aggregate Concrete, Advanced Materials Research, (2011), 163-167, 1762-1767, doi:10.4028/www.scientific.net/AMR. 163-167.1762

${ }^{27}$ M. S. Nadesan, P. Dinakar, Mix design and properties of fly ash waste lightweight aggregates in structural lightweight concrete, Case Studies in Construction Materials, (2017) 7, 336-347, doi:10.1016/ j.cscm.2017.09.005

${ }^{28}$ T. C. Hansen, Recycled aggregate and recycled aggregate concrete, Material and Structures (RILEM), 19 (1986) 111, 201-204

${ }^{29}$ C. Lian, Y.Zhuge, S.Beecham, The relationship between porosity and strength for porous concrete, Construction and Building Materials, 25 (2011) 11, 4294-4298, doi:10.1016/j.conbuildmat.2011.05.005

${ }^{30}$ B. B.Sabir, S. Wild, M. O'Farrell, A water sorptivity test for mortar and Concrete, Materials and Structures (RILEM), 1998, 31, 568-574

${ }^{31}$ M. G. Alexander, durability indexes and their use in concrete engineering, Department of Civil Engineering, University of Cape Town, 2016, South Africa

${ }^{32}$ N. Divyah, R. Thenmozhi, M. Neelamegam, A comparative study on prediction models for strength properties of LWA concrete using artificial neural network, Journal of Construction, 19 (2020), 1, 103-111 doi:10.7764/RDLC.19.1.103-111

${ }^{33}$ R. Prakash, R. Thenmozhi, S. N. Raman, C. Subramanian, N. Divyah, An investigation of key mechanical and durability properties of coconut shell concrete with partial replacement of fly ash, Structural Concrete, (2020), 1-12, doi:10.1002/suco.201900162 